\title{
GENETIC ANALYSIS OF F 2 DIALLEL CROSSES IN DURUM WHEAT
}

\author{
Gh. A. T. A. Al - Hamdany \\ Dept. of Biology, College of Science, Mosul University
}

\begin{abstract}
Inheritance of yield, combining ability and inbreeding depression were investigated in durum wheat of $F_{2}$ half diallel crossing among the 7 varieties Vis: Leeds, Waha, Azeghar1, Um-Rabie3, Brashua, Cyprus1 and Korfila. Genotypes, general and specific combining ability mean square were highly significant. The durum wheat yield was under the dominance gene effect. The parents Leeds and Um-Rabie3 were considered suitable according to their yield capacities and general combining ability effects. The two hybrids (Leeds x Brashua) and (Waha $\mathrm{x}$ Brashua) had significantly higher yield (2.943 and 2.955 ton per hectare respectively) as compared with others, and also possessed significant positive specific combining ability effects, highly significant positive inbreeding depression values and deviation from local variety Um-Rabei5, therefore they were considered to be promising hybrids.
\end{abstract}

\section{INTRODUCTION}

Durum or macaroni wheat, Triticum durum, $(2 \mathrm{n}=4 \mathrm{x}=28$, genomes AABB $)$, is grown on about 30 million hectares and accounts for almost 8 percent of total world wheat production. Recently,Fawzi(2001), durum wheat has received proper attention of geneticists and breeders resulting in gathering of information on the nature and magnitude of gene effects governing the inheritance of yield and other quantitative traits.

Several breeding methods have been established to increase the yields of durum wheat varieties and their hybrids. In order to choose the best hybrid combinations a large number of subjectively chosen varieties are crossed. It would be a considerable advantage to be able to estimate the combining ability of parents, gene effects and heterotic effects of crosses before making crosses among varieties. Diallel crossing programs have been applied to achieve this goal by providing a systematic approach for the detection of suitable parents and crosses for the investigated characters. In addition, diallel analysis gives plant breeders the opportunity to choose the most efficient selection method by allowing them to estimate several genetic parameters ,Singh and Ghaudhary(1979).

Combining ability describes the breeding values of parental lines to produce hybrids. Sprague and Tatum (1942) used the term general combining ability (gca) to designate the average performance of a variety in hybrid combinations, and used the term specific combining ability (sca) to define those cases in which certain combinations do relatively better or worse than would be expected on the basis of the average performance of the varieties involved. In many studies, gca effects for parents and sca effects for crosses were estimated in wheat (Saad, 1999; Hamada et al., 2002; Iqbal and Khan 2006; Kamaluddin et al., 2007). Non additive gene effects for yield were found to be significant in wheat (Dere and Yildirim, 2006; Amein, 2007 ;Abd-El-Haleem et al., 2009). In addition, heritability degrees varied from low to moderate for yield (Aycicek and Yildirim, 2006; Yagdi and Sozen, 2009; Maniee et al., 2009).

Inbreeding depression is defined as the deviation of $F_{1}$ mean from $F_{2}$ one of the same hybrid, and generally high positive values are desirable for yield in durum Received 14/12/2009 accepted 1/3/2010 
wheat. Abd-El-Haleem et al.,(2009) found negative inbreeding depression values for the most of hybrids from their study on durum wheat, indicating yield depression in $F_{2}$ generation. The objectives of this study were to estimate the genetic parameters and inbreeding depression and to determine suitable parents and promising crosses for yield in $\mathrm{F}_{2}$ half diallel among seven durum wheat varieties.

\section{MATERIALS AND METHODS}

Seven varieties,Vic; Leeds, Waha, Azeghar1, Um-Rabie3, Brashua, Cyprus1 and Korfila obtained from IPA center for Agricultural Research and Field Crops Depts., College of Agric., and Forestry, Mosul Univ., were crossed in using half diallel mating scheme in the 2003-2004 growing season. $F_{2}$ were obtained from selfing of $F_{1 ' s .}$. The parents, their $21 \mathrm{~F}_{2}$ populations and a commercial variety that registered in Iraq (Um-Rabie5), 29 entries in total, were grown at Field Crops Dept. farm, center of Mosul University in the 2007-2008 growing season. The plots were represented by three rows, $3 \mathrm{~m}$ long and spaced $20 \mathrm{~cm}$ apart with sowing rates of $140 \mathrm{~kg}$ per hectare. The experimental design was a randomized complete block design with 3 replications. Cultural practices were consistent with the production of wheat according to the recommendations of Iraqi Ministry of Agriculture, and yield of each genotype (variety or hybrid) was obtained from each plot and transformed to ton per hectare. Data obtained from the $21 \mathrm{~F}_{2}$ progeny and 7 parents were analyzed by Jinks-Hayman type diallel analysis for genetic parameters as outlined by Singh and Chaudhary (2007) and the following parameters and rations were estimated:

$\mathrm{E}=$ The expected environmental component of variation $=[($ Error SS + Reps. SS $)$ $/$ d.f] $/ \mathrm{r}$

$\mathrm{D}=$ Variation due to additive effect of the gene.

$\mathrm{H}_{1}=$ Component of variation due to the dominance effect of the gene.

$\mathrm{H}_{2}=$ Corrected dominance variance.

$\mathrm{h}^{2}=$ Dominance effect (as the algebric sum over all loci in heterozygous phase in all crosses

$\mathrm{F}=$ The mean of $\mathrm{Fr}$ (cov. of additive $\&$ dominance effects in a single array) over the arrays.

$\left(\mathrm{H}_{1} / \mathrm{D}\right)^{1 / 2}=$ Mean degree of dominance.

$\mathrm{KD} / \mathrm{KR}=$ Proportion of dominant and recessive genes in the parents.

$\mathrm{H}_{2} / 4 \mathrm{H}_{1}=$ Proportion of genes with positive and negative effects in the parents.

$\mathrm{K}\left(\mathrm{h}^{2} / \mathrm{H}_{2}\right)=$ Number of groups of genes which control the character and exhibit dominance. Griffing's Method 2 Model 1 was used to analyze combining abilities (Griffing, 1956). The analysis were performed using (SAS program), Inbreeding depression (I) values were calculated as deviation of expected $\mathrm{F}_{1}$ means $\left(\mathrm{EF}_{1}\right)$ for each hybrid from $F_{2}$ means (Gomma and Shaheen, 1995 and Hassan, 1997). The expected $\mathrm{F}_{1}$ means estimated from the equation suggested by Mather and Jinks (1982) $\left[\mathrm{EF}_{1}=2 \mathrm{~F}_{2}-1 / 2 \mathrm{P}_{1}-1 / 2 \mathrm{P}_{2}\right]$, and the significance of inbreeding depression was investigated by t-test $[t=(I-0) / S E I]$, where SEI mean standard error of inbreeding depression and estimated from the difference between variance of $F_{1}$ mean $\left(\mathrm{VF}_{1}\right)$ and variance of $\mathrm{F}_{2}$ mean $\left(\mathrm{VF}_{2}\right)$. Narrow sense heritability degree was calculated according to the methods of Crumpacker and Allard (1962) as reviewed by (Singh and Chaudhary, 2007).

\section{RESULTS AND DISCUSSION}

The analysis of variance for genotypes, and later for combining ability in durum wheat are presented in table 1. It was shown that genotypes mean square was 
highly significant for yield per hectare, which suggested the importance of studying the gene action for this character. General and specific combining ability mean square were also highly significant, indicated the importance of additive and non additive gene effects in the inheritance of this characters

Table (1): Mean square obtained from primary analysis and combining abilities in diallel durum wheat crosses among 7 varieties.

\begin{tabular}{|c|c|c|}
\hline Source of variation & d. f. & Mean Squares \\
\hline Replication & 2 & 0.00019 \\
\hline Genotype & 27 & $0.11814^{* *}$ \\
\hline Error (Preliminary) & 54 & 0.00135 \\
\hline General Combining Ability & 6 & $0.06255^{* *}$ \\
\hline Specific Combining Ability & 21 & $0.13402^{* *}$ \\
\hline Error (for combining ability) & 54 & 0.00045 \\
\hline \hline \multicolumn{2}{|c|}{ gca/sca } & 0.467 \\
\hline
\end{tabular}

$(* *)$ indicate significant at $1 \%$ level.

The genetic parameters for the yield per hectare estimated from $\mathrm{F}_{2}$ half diallel cross population among the seven varieties included in this study are given in Table (2).

Table(2): Genetic parameters and ratios estimated from 7 x 7 diallel cross in durum wheat.

\begin{tabular}{|c|c|}
\hline Genetic parameters and ratios & Grain yield (ton/hectare) \\
\hline $\mathrm{F}$ & $0.05494 \pm 0.04209$ \\
\hline $\mathrm{h}^{2}$ & $0.18700 \pm 0.01244$ \\
\hline $\mathrm{E}$ & $0.00044 \pm 0.00296$ \\
\hline $\mathrm{D}$ & $0.03979 \pm 0.02092$ \\
\hline $\mathrm{H}_{1}$ & $0.17771 \pm 0.02623$ \\
\hline $\mathrm{H}_{2}$ & $0.06900 \pm 0.01775$ \\
\hline$\left(\mathrm{H}_{1} / \mathrm{D}\right)^{1 / 2}$ & 2.003 \\
\hline $\mathrm{KD} / \mathrm{KR}=\left[(4 \mathrm{DH})^{1 / 2}+\mathrm{F}\right] /\left[\left(4 \mathrm{DH}_{1}\right)^{1 / 2}-\mathrm{F}\right]$ & 1.970 \\
\hline $\mathrm{K}\left(\mathrm{h}^{2} / \mathrm{H}_{2}\right)$ & 2.71 \\
\hline $\mathrm{Heritability} \mathrm{Degree}(\mathrm{Narrow}$ Sense $)$ & 0.0643 \\
\hline$\Gamma(\mathrm{Yr}, \mathrm{Wr}+\mathrm{Vr})$ & -0.614 \\
\hline & $\Gamma_{(5.0 .01)}$ \\
\hline & $\mathrm{I}_{(5,0.05)}=0.874$ \\
\hline
\end{tabular}

(ns) indicate non significant.

While a negative $\mathrm{F}$ value indicates an excess of recessive alleles in the parents, a positive value shows more dominant alleles than recessive in the parents. Crampacker and Allard (1962) reported that, if the dominant and recessive alleles of each gene are distributed equally among the parents, the $\mathrm{F}$ value will be equal to zero. In the present study and as an indicator of the relative frequency of dominant and recessive alleles, the $\mathrm{F}$ value was found to be positive and significant from zero $(=0.05494)$ which means either that no alleles exhibit dominance or else that the dominant and recessive alleles are distributed equally among the parents (Verhalen and Murray, 1967). From the other results of the study, the latter alternative may apply since the variances for $\mathrm{H}_{1}$ and $\mathrm{H}_{2}$ are significantly different from zero. It may thus be concluded that the dominant and recessive alleles of the related genes are 
distributed equally among the parents. Since the mean dominance effect of the heterozygote locus $\left(h^{2}\right)$ was significant, high heterotic effect values in $F_{2}$ (or positive significant inbreeding depression values) would be expected for durum wheat yield among crosses. The parameters (E), an estimate of environmental variation was not different from zero, and (D), the estimate of additive genetic variance was different from zero (Table 2). The parameter (D), which may also include a portion of the additive $\mathrm{x}$ additive epistatic variances as well as additive genetic variance itself, was significant for yield. Dominance variance $\left(\mathrm{H}_{1}\right)$ and corrected dominance variance $\left(\mathrm{H}_{2}\right)$ were also significantly different from zero (= 0.17771 and 0.069 respectively), but its values are higher than additive one. It may thus be concluded that dominante gene effects more important in the inheritance of this characters. This result was also supported by the ratio (less than unity) of gca/sca mean square (0.467). Dere and Yildirim (2006), Amein (2007) and Abd-ElHaleem et al. (2009) obtained similar results in wheat. As the ratio $\mathrm{h}^{2} / \mathrm{H}_{2}$ (k value) equal 2.71, approximately three genes will control durum grain yield. The estimate of narrow sense heritability was low (0.0358), and consistent with other researchers results, like Aycicek and Yildirim (2006) and Yagdi and Sozen (2009). The negative (but non significant) correlation value between ( $\mathrm{Yr}$ and $\mathrm{Wr}+\mathrm{Vr}=-0.614$ ) indicates that the parents with high grain yield may carry dominant genes.

The inheritance of yield is shown in a $\mathrm{Wr}-\mathrm{Vr}$ graph in Figure 1. Partial dominance may be inferred from this graph since the regression line cut the $\mathrm{Wr}$ axis over the origin.

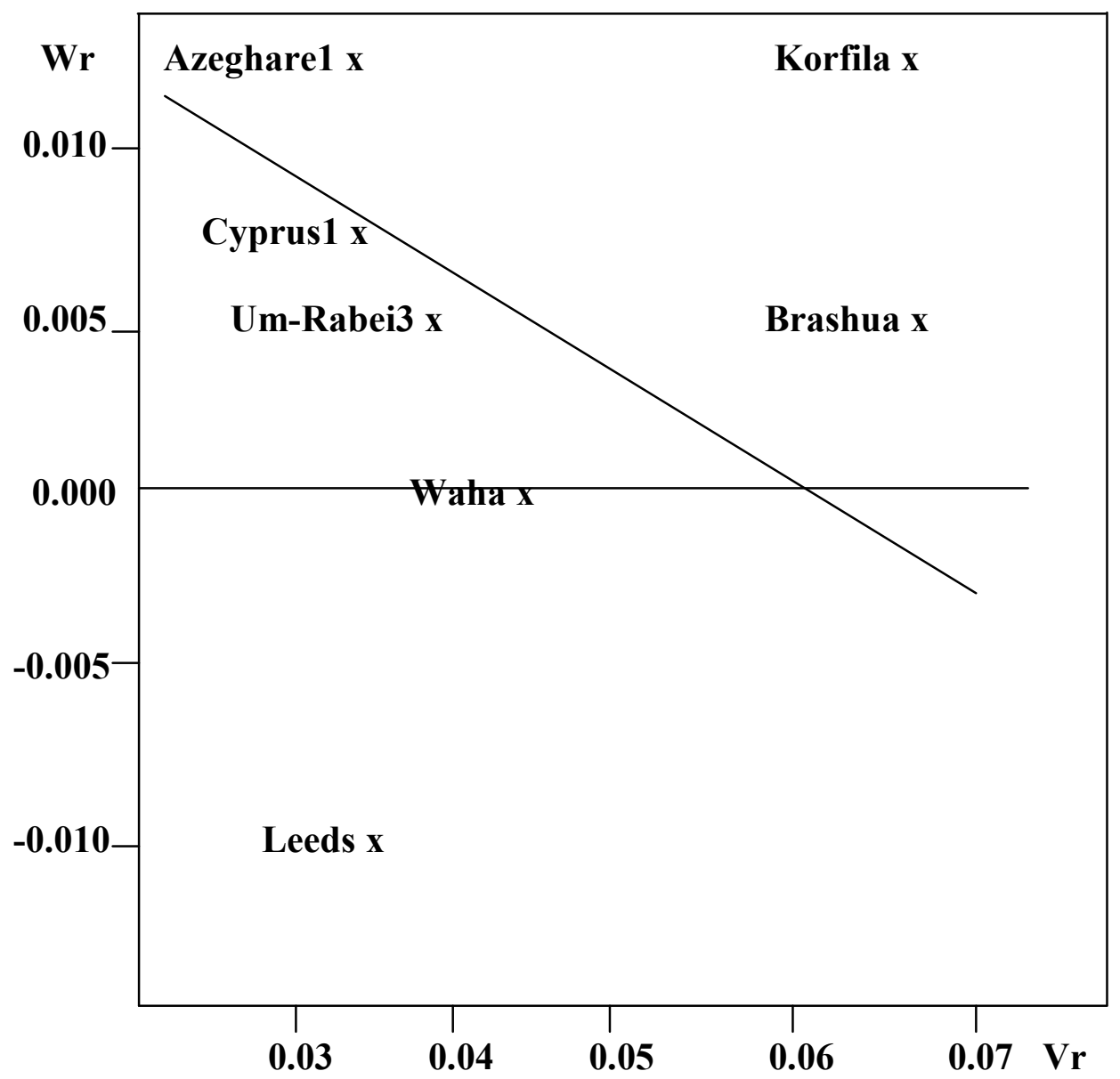

Figure( 1): Covariance-variance F2 diallel crosses graph for yield in durum wheat. 
With regards to yield, the varaieties Leeds, Waha and Um - Rabei3 had more dominant genes whereas Korfila and Brashua carried more recessive genes. Means of durum wheat yield and gca effects of parents are given in Table 3. Duncan's multiple range test showed significant differences for yield among parents.

Table (3): Mean of Parents and general combining ability (gca) effects for grain yield.

\begin{tabular}{|c|c|c|}
\hline Parents & Yield $(\mathrm{t} / \mathrm{h})$ & gca effect \\
\hline Leeds & $2.800 \mathrm{a}$ & $0.069503^{*}$ \\
\hline Waha & $2.440 \mathrm{~cd}$ & $-0.02398^{*}$ \\
\hline Azeghar1 & $2.640 \mathrm{~b}$ & $0.011429^{*}$ \\
\hline Um-Rabie3 & $2.840 \mathrm{a}$ & $0.046243^{*}$ \\
\hline Brashua & $2.320 \mathrm{e}$ & $-0.06502^{*}$ \\
\hline Cyprus1 & $2.400 \mathrm{de}$ & $-0.04428^{*}$ \\
\hline Korfila & $2.520 \mathrm{c}$ & 0.006095 \\
\hline Um-Rabie5 (Commercial) & $2.738 \mathrm{a}$ & ---- \\
\hline S. E. (gca effect) & & 0.010002 \\
\hline
\end{tabular}

$(*)$ indicate significant from zero.

- yield means followed by the same letter have non significant difference among them.

While varieties Leeds, Um-Rabie3 and commercial one Um-Rabie5 can be considered significantly high yielding as compared with others $(2.800,2.840$ and 2.738 ton / hectare respectively), The two parents Leeds and Um-Rabie3 had higher yield and statistically significant and desirable gca effects.Means of specific combining ability effects, inbreeding depression and deviation from commercial variety (Um-Rabie5) values for crosses are given in Table 4. The two crosses, (Leeds x Brashua) and (Waha x Brashua) had significantly higher yield capacities as compared with others (2.943 and 2.995 ton per hectare respectively). These two $\mathrm{F}_{2}$ crosses also had significantly higher and desirable specific combining ability effects and desirable deviation from expected $\mathrm{F}_{1}$ and commercial variety UmRabie5. Seven crosses had significant non desirable specific combining ability effects for this character. Most of the best performing crosses usually had at least one parent with high gca effects Chaudhary et al.,(2000). It was shown that sixteen of the crosses had significant positive deviation of $F_{2}$ from expected $F_{1}$, but depression in $F_{2}$ occurred significantly in crosses (Leeds $x$ Um-Rabie3), (Leeds $x$ Cyprus1) and (Waha $x$ Azeghar1) only, and non significantly in the cross (UmRabie3 x Brashua). This results are supported with findings ofAbd-EL- Haleem et al., (2009) whom reported the occurrence of depression (as a result of inbreeding) in durum wheat yield in $\mathrm{F}_{2}$ generation. While eleven $\mathrm{F}_{2}$ hybrids significantly surpassed the commercial variety Um-Rabie5, seven varieties significantly and negatively deviated from them. 
Table (4): Mean yield, specific combining ability (sca) effects \& inbreeding depression values of crosses.

\begin{tabular}{|c|c|c|c|c|}
\hline Crosses & Yield(t/h) & $\begin{array}{c}\text { sca } \\
\text { Effects }\end{array}$ & $\begin{array}{l}\text { Inbreeding } \\
\text { depression }\end{array}$ & $\begin{array}{c}\text { Deviation from } \\
\text { Um-Rabei } \\
\text { Variety }\end{array}$ \\
\hline Leeds x Waha & $2.835 \mathrm{de}$ & $0.103^{*}$ & $0.215^{* *}$ & $0.097^{* *}$ \\
\hline Leeds x Azeghar1 & $2.868 \mathrm{bcd}$ & $0.101 *$ & $0.148^{* *}$ & $0.130^{* *}$ \\
\hline Leeds x Um-Rabie3 & $2.507 \mathrm{ij}$ & $-0.295^{*}$ & $-0.313 * *$ & $-0.231 * *$ \\
\hline Leeds x Brashua & $2.943 \mathrm{a}$ & $0.252 *$ & $0.383^{* *}$ & $0.205^{* *}$ \\
\hline Leeds x Cyprus 1 & $2.477 \mathrm{jk}$ & $-0.234^{*}$ & $-0.123 * *$ & $-0.261 * *$ \\
\hline Leeds x Korfila & $2.885 \mathrm{bc}$ & $0.124^{*}$ & $0.225^{* *}$ & $0.147 * *$ \\
\hline Waha x Azeghar1 & $2.437 \mathrm{k}$ & $-0.236^{*}$ & $-0.103 * *$ & $-0.301 * *$ \\
\hline Waha x Um-Rabie3 & $2.788 \mathrm{f}$ & $0.079^{*}$ & $0.148 * *$ & 0.050 \\
\hline Waha x Brashua & $2.955 \mathrm{a}$ & $0.358^{*}$ & $0.575^{* *}$ & $0.217^{* *}$ \\
\hline Waha x Cyprus 1 & $2.793 \mathrm{f}$ & $0.175^{*}$ & $0.373^{* *}$ & $0.055^{*}$ \\
\hline Waha x Korfila & $2.585 \mathrm{~h}$ & $-0.083^{*}$ & $0.105^{* *}$ & $-0.153 * *$ \\
\hline Azeghar1 x Um-Rabie3 & $2.801 \mathrm{ef}$ & $0.058^{*}$ & $0.061 *$ & $0.063^{*}$ \\
\hline Azeghar1 x Brashua & $2.487 \mathrm{jk}$ & $-0.146^{*}$ & 0.007 & $-0.251 * *$ \\
\hline Azeghar1 x Cyprus1 & $2.845 \mathrm{~cd}$ & $0.192 *$ & $0.325^{* *}$ & $0.107 * *$ \\
\hline Azeghar1 x Korfila & $2.873 \mathrm{bcd}$ & $0.169^{*}$ & $0.293 * *$ & $0.135^{* *}$ \\
\hline Um-Rabie3 x Brashua & 2.3731 & $-0.294 *$ & -0.207 & $-0.365^{* *}$ \\
\hline Um-Rabie3 xCyprus1 & $2.900 \mathrm{~b}$ & $0.212^{*}$ & $0.280^{* *}$ & $0.162^{* *}$ \\
\hline Um-Rabie3 x Korfila & $2.856 \mathrm{~cd}$ & $0.118^{*}$ & $0.176^{* *}$ & $0.118^{* *}$ \\
\hline Brashua x Cyprus1 & $2.739 \mathrm{~g}$ & $0.162 *$ & $0.379^{* *}$ & 0.001 \\
\hline Brashua x Cyprus1 & $2.768 \mathrm{fg}$ & $0.141^{*}$ & $0.348^{* *}$ & 0.030 \\
\hline Cyprus1 x Korfila & $2.536 \mathrm{i}$ & $-0.112 *$ & $0.076^{* *}$ & $-0.202 * *$ \\
\hline S.E. (sca effect) & & 0.028 & & \\
\hline
\end{tabular}

$(*)$ and $(* *)$ for heterosis indicate significant at $5 \%$ and $1 \%$ levels, respectively.

$(*)$ for sca effects indicate significant from zero.

yield means followed by the same letter have non significant difference among them.

\section{التحليل الوراثي للتهجينات التبادلية للجيل الثاني في الحنطة الخثنة

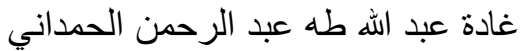

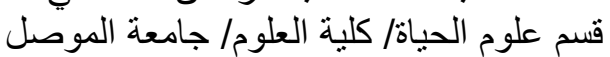

\section{الخلاصة}

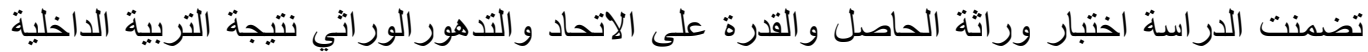

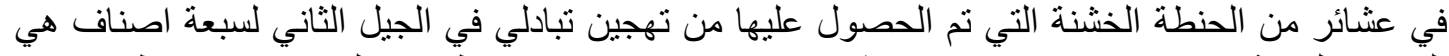

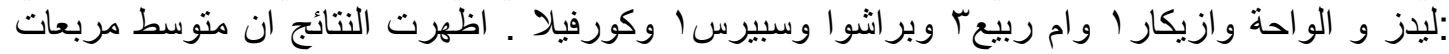

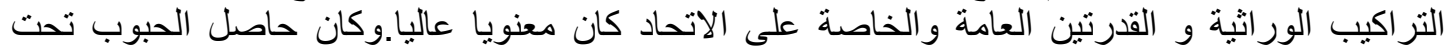

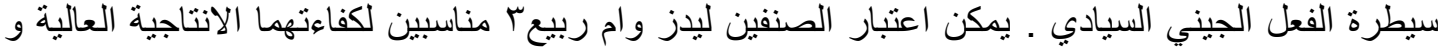

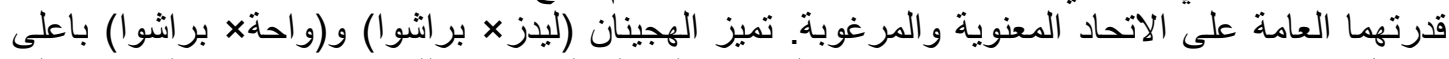

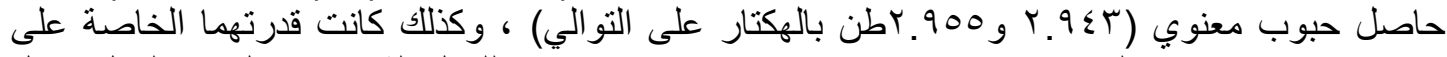

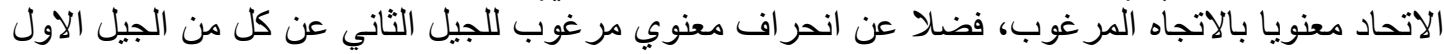

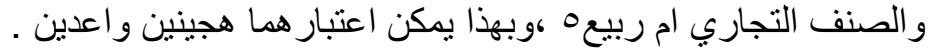

\section{REFERENCES}

Abd-El-Haleem, S. H. M., M. A. Reham and S. M. S. Mohamed (2009). Genetic Analysis and RAPD polymorphism in some durum wheat genotypes. Global J. of Biotech. \& Biochem. 4 (1): 01-09 
Amein, K.A., (2007). Genetic improvement of grain quality in some cereal crops, protein quality and quality in wheat (Triticum aestivum L.). Ph.D. Thesis, Fac. of Agric., Assiut Univ., Egypt.

Aycicek, M. and T. Yildirim (2006). Heritability of Yield and Some yield component in bread wheat (Triticum aestivum L. ) genotypes. Bangladesh J. Bot. 35(1): 17-22.

Crumpacker, D. W. and R. W. Allard (1962). A diallel cross analysis of heading date in wheat. Hilgardia, 32: 275-318.

Chaudhary, A. K., L. B. Chaudhary and K. C. Sharma (2000). Combining ability estimate of early generation inbred derived from two maize populations. Ind. J. Genet. and Plant Breeding, 60: 55-61.

Dere, F. and M. B. Yildirim (2006). Inheritance of grain yield per plant, flag leaf width, and length in an $8 \times 8$ diallel cross population of bread wheat $(T$. aestivum L.). Turk. J. Agric, 30: 339-345.

Fawzi,Mazin.(2001).Effects of durum wheat and its quality by planting dates and seed rates .PhD Thesis, Crop field science Dept. College of Agric .Baghdad Univ. Iraq

Gomma, M. A. M. and A. M. A. Shaheen (1995). Heterosis, inbreeding depression, heritability and type of gene action in two intra-barbadense cotton crosses. Annals Agric. Sci. Ain Shams Univ. 40(1):165-176.

Griffing, B. (1956). Concept of general and specific combining ability in relation to diallel crossing systems, Aus. J. Biol. Sci. 9:463-493.

Hamada, A.A., E.H. El-Seidy and H.I. Hendawy, 2002. Breeding measurements for heading date, yield and yield components in wheat using line $\times$ tester nalysis. Ann. Agric. Sci. Cairo, 47: 587-609.

Hassan, E. E. (1997). Combining ability and factor analysis in durum wheat (Triticum turgidum). Zagazig J. Agric. Res. 24(1): 23-36.

Iqbal, M. and A. A. Khan (2006). Analysis of combining ability for spike characteristic in Wheat. Nt. J. Agri. Biol. 8(5): 884-687.

Kamaluddin, R. M. Singh, L. C. Prasad, M. Z. Abdin and A. K. Joshi (2007). Combining ability analysis for grain filling duration and yield traits in spring wheat (Triticum aestivum L. em. Thell.), Genetics and Molecular Biology, 30(2): 411-416.

Maniee, M., D. Kahrizi and R. Mohammadi (2009). Genetic variability of some Morphp- Physiological traits in durum wheat (Triticum turgidum var. Durum). J . Applied Sci.9(7):1383-1387.

Mather,K. and Jinks,J.L.(1982).Biometrical Gen. Chapman and Hall Ltd.3 ${ }^{\text {rd }}$.ed.,396 pp.

Saad, F.F., 1999. Heterosis parameters and combining ability for crosses among Egyptian and Austrian durum wheat entries. Assiut J. Agric. Sci., 30: 31-42

SAS(Statistical Analysis System V. 9) and Microsoft Office Excel 2003.

SinghI, R.K. and B. D. Chaudhary(2007). Biometrical Methods in Quantitative Genetic Analysis. Kalyani Publisher, New Delhi. Pp318.

Sprague, G. F. and L. A. Tatum (1942). General vs specific combining ability in single crosses of corn. J. Am. Soc. Agron. 34: 923-932.

Verhalen, L. M. and J. C. Murray (1967). A diallel analysis of several fiber property traits in upland cotton. Crop Sci. 7: 501-505.

Yagdi K. and E. Sozen (2009). Heritability, variance components and correlations of yield and quality traits in durum wheat (Triticum durum Desf.). Pak. J. Bot., 41(2): 753-759. 